\title{
Poverty reduction among beef cattle value chain actors in North-West zone of
} Nigeria

${ }^{1}$ Rekwot, G. Z., ${ }^{2}$ Oyinbo, O. and ${ }^{1}$ Achi, N. P.

${ }^{\prime}$ National Animal Production Research Institute, Ahmadu Bello University, Zaria, Nigeria

${ }^{2}$ Department of Agricultural Economics, Ahmadu Bello University,

Zaria, Nigeria

Corresponding author:zrekwot@gmail.com:+2348038013957

\section{Abstract}

This paper provides a valuable guide in defining interventions relevant for addressing various actors and determining the expected poverty reducing effects that such interventions can produce in the beef cattle value chain. The objective of this paper was to provide empirical information on the relationship between income generated from beef cattle value chain and poverty status of value chain actors in Nigeria. The study was conducted in Kaduna, Kano and Katsina states, twelve villages were purposively selected (two from each $L G A)$ and one cattle market in each of the six LGAs was randomly selected to give a sample of six cattle markets. A multi-stage sampling technique was employed in the selection of the respondents. A sample size of 300 value chain actors consisting of 120 beef cattle farmers, 60 beef cattle traders, 60 raw beef marketers and 60 processed beef marketers was utilized in the study. The study made use of primary data, which were obtained through the use of computeraided personal interview (CAPI) software on tablets. Analysis of the data was done using descriptive statistics, Foster-Greer-Thorbecke's (FGT) weighted poverty index and Pearson correlation analysis. The results of the poverty profile offarmers, traders, raw and processed beef cattle marketers in the study area showed that 55\%, 32\%, 40\% and 38\% of the raw and processed beef marketers respectively constituted the share of the population that cannot afford to buy a basic basket of goods (food and non-food) equivalent to the poverty line of $N 75,600$. The depth of poverty of poor beef cattle traders (0.08) was lower than that of the poor beef cattle farmers (0.17), raw beef marketers (0.10) and processed beef marketers (0.14). The degree of poverty among the poor beef cattle traders given by the estimated severity of poverty (0.03) was equally lower than that of the poor beef cattle farmers (0.08), raw beef marketers (0.04) and processed beef marketers (0.07). Participation in beef cattle value chain activities as given by the income generated is strongly associated to the likelihood of poverty reduction among the value chain actors as indicated by the correlation coefficients of -0.53, -0.66., -0.64 and -0.71 between income generated from beef cattle value chain and poverty status of the cattle farmers, traders, raw beef marketers and processed beef marketers respectively. It is recommended that beef value chain actors should take advantage of the huge potential investment opportunities in beef cattle value chain activities.

Keywords: Income, poverty, value chain, beef cattle, pearson correlation

\section{Réduction de la pauvreté parmi les acteurs de la chaîne de valeur des bovins de boucherie dans la zone nord-ouest du Nigeria}

\section{Résumé}

Ce document fournit un guide précieux pour définir les interventions pertinentes pour s'adresser à divers acteurs et déterminer les effets escomptés de réduction de la pauvreté que de telles interventions peuvent produire dans la chaîne de valeur des bovins de boucherie. L'objectif de cet article était de fournir des informations empiriques sur la relation entre les 


\section{Poverty reduction among beef cattle value chain actors}

revenus générés par la chaîne de valeur des bovins de boucherie et le statut de pauvreté des acteurs de la chaîne de valeur au Nigeria. L'étude a été menée dans les États de Kaduna, Kano et Katsina, douze villages ont été choisis à dessein (deux dans chaque LGA) et un marché aux bestiaux dans chacune des six LGA a été sélectionné au hasard pour donner un échantillon de six marchés aux bestiaux. Une technique d'échantillonnage à plusieurs degrés a été utilisée pour la sélection des répondants. Un échantillon de 300 acteurs de la chaîne de valeur comprenant 120 éleveurs de bovins de boucherie, 60 commerçants de bovins de boucherie, 60 commerçants de bouf cru et 60 commerçants de bœuf transformé a été utilisé dans l'étude. L'étude a utilisé des données primaires, qui ont été obtenues grâce à l'utilisation d'un logiciel d'entretien personnel assisté par ordinateur (EPAO) sur des tablettes. L'analyse des données a été effectuée à l'aide de statistiques descriptives, de l'indice de pauvreté pondéré de Foster-Greer-Thorbecke (FGT) et de l'analyse de corrélation de Pearson. Les résultats du profil de pauvreté des agriculteurs, commerçants, commerçants de bœu cru et transformé dans la zone d'étude ont montré que 55\%, 32\%, 40\% et $38 \%$ des commerçants de bouf cru et transformé constituaient respectivement la part de la population qui ne peut pas se permettre d'acheter un panier de base de biens (alimentaires et non alimentaires) équivalent au seuil de pauvreté de N75, 600. La profondeur de la pauvreté des commerçants pauvres de bovins de boucherie $(0,08)$ était inférieure à celle des éleveurs pauvres de bovins de boucherie $(0,17)$, les commerçants de bøuf cru $(0,10)$ et les commerçants de bœuf transformé $(0,14)$. Le degré de pauvreté parmi les commerçants pauvres de bovins de boucherie donné par la gravité estimée de la pauvreté $(0,03)$ était également inférieur à celui des éleveurs pauvres de bovins de boucherie (0,08), des commerçants de bouf cru $(0,04)$ et des commerçants de bouf transformé $(0,07)$. La participation aux activités de la chaîne de valeur des bovins de boucherie telle que donnée par les revenus générés est fortement associée à la probabilité de réduction de la pauvreté parmi les acteurs de la chaîne de valeur, comme indiqué par les coefficients de corrélation de -0,53, -0,66., -0,64 et -0,71 entre les revenus générés par chaîne de valeur des bovins de boucherie et statut de pauvreté des éleveurs de bétail, des commerçants, des commerçants de bœuf cru et des commerçants de bœuf transformé respectivement. Il est recommandé que les acteurs de la chaîne de valeur du bœuf tirent parti des énormes opportunités d'investissement potentielles dans les activités de la chaîne de valeur du bouf.

Mots-clés : Revenu, pauvreté, chaîne de valeur, bovins de boucherie, corrélation de Pearson

\section{Introduction}

Agriculture provides livelihoods to more than one billion people worldwide and remains the back bone of many lowincome countries, accounting for 60.4 percent of employment and contributing up to two-thirds of gross domestic product in some of those countries (East African Business Council (EABC, 2020). The Nigeria agricultural sector holds the key to the country's drive for economic diversification. Agricultural sector remains the largest employer of labour in the country, providing jobs for more than one third $(36.4 \%)$ of the Nigerian labour force (PrincewaterhouseCoopers $\{\mathrm{PWC}\}$, 2020). However, agriculture in Nigeria still faces many challenges such as adverse weather conditions associated with climate change, herder-farmer clashes, terrorism in the northeast, cattle rustling, low level of mechanization and poor research and development activities (PWC, 2020).

In the face of dwindling oil revenue and the urgent need for diversification of Nigerian economy by unlocking the potentials of agriculture, agricultural value chains offer 


\section{Rekwot, Oyinbo and Achi}

a good platform for such diversification (Muftah, 2017; Adesoye, Adelowokan, Maku and Salau, 2018; Ademola, Olawale and Abiodun, 2019). This is especially for the under-developed livestock value chains such as beef, dairy, poultry, pig, sheep and goat value chains as envisioned under the Agricultural Transformation Agenda (ATA) (2011 - 2015) and reinvigorated in the APP. More recently, a National Livestock Transformation Plan (NLTP) (2019 - 2028) approved by the National Economic Council of Nigeria seeks to build on and take to a new level the broader goals of the APP (Federal Ministry of Agriculture and Rural Development (FMARD), 2019). Implementing policies towards harnessing the potentials of the livestock subsector can contribute immensely to the much-needed diversification (Abubakar and Ibrahim, 2019).

With a growing rate of employment (NBS, 2018) and incidence of poverty in the study area and other parts of Nigeria (United Nations Development Programme (UNDP), 2018), it has become expedient to explore opportunities in both crop and livestock sub-sectors to address these negative trends. However, evidence on the causal effect of livestock value chains particularly the effect of participation in beef cattle value chain on poverty reduction amongst various actors along the value chain is limited amidst the incessant farmers-herders conflicts and cattle rustling. In other words, a gap exists in literature on the existence and magnitude of poverty reducing effects of participation in beef cattle value chain by the actors and the differential effects among the various beef cattle value chain actors. Therefore, the objective of the study was to determine the relationship between income generated from beef cattle value chain and poverty status of value chain actors.

\section{Materials and methods \\ Description of the study area}

The north-west comprise of Jigawa, Kano, Katsina, Kaduna, Zamfara, Sokoto and Kebbi states.However, the study was conducted in Kaduna, Kano and Katsina states. According to the 2006 population census, the total population of the zone is estimated at 35.7 million with an average density of 103 persons per square kilometer (National Population Commission (NPC), 2006). The projected population of the zone in 2018 is about 48.3 million, based on an annual growth rate of $3.2 \%$. The north-west zone is known for livestock production activities such as cattle, goat, sheep, poultry etc. The zone produced over half of the entire cattle in the country in the national agriculture sample survey with 9,892,240 cattle heads representing $52.4 \%$ of cattle in Nigeria (NBS/FMARD, 2012).Kaduna, Katsina and Kano States had 655,382, 2,008,592 and 546,303 cattle heads respectively (NBS/FMARD, 2012).

Sampling procedure and sample size

Four categories of respondents (value chain actors) formed the sample for this study. These were beef cattle farmers, beef cattle traders, raw and processed beef marketers (wholesalers, retailers, suya producers, kilishi producers, danbunnama producers). Multi-stage sampling technique was employed in the selection of the value chain actors. The selection of the sample for each actor was carried out in the following manner.

Beef cattle farmers: In the selection of beef cattle farmers, six Local Government Areas (LGAs) were purposively selected (two from each state) based on their prominence in cattle production (LGAs that have several communities involved in cattle farming), availability of cattle markets. Secondly, twelve villages were purposively selected (two from each LGA) on the basis of high availability of pastoralists and agropastoralists. Thirdly, ten beef cattle farmers 
were randomly selected in each of the villages to give a sample size of 120 beef cattle farmers derived from a list of cattle farmers obtained in the villages with the assistance of extension agents and the community leaders. Equal sample size was used due to lack of information on the population of beef cattle farmers.

Beef cattle traders: In the selection of cattle traders, one cattle market in each of the six LGAs was randomly selected to give a sample of six cattle markets and a list of cattle traders was obtained from the cattle traders associations in each of the markets. Ten cattle traders in each of the markets were randomly selected to give a sample size of 60 cattle traders. Equal sample size was used due to lack of information on the population of beef cattle traders.

Raw and processed beef marketers: In the selection of beef marketers, 10 raw beef marketers (wholesalers and retailers) and 10 processed beef marketers (suya producers, kilishi producers and danbunnama producers) were randomly selected in each of the six LGAs to give a sample size of 60 raw beef marketers and 60 processed beef marketers derived from a list of raw and processed beef marketers compiled with the assistance of extension agents and the beef marketers associations. Equal sample size was used due to lack of information on the population of the actors in their respective market segments.
The total sample size of the study was 300 . The study made use of primary data. Primary data were obtained through the use of computer-aided personal interview (CAPI) version of survey instrument rather than paper-based questionnaire.

\section{Foster-Greer-Thorbecke's (FGT) Weighted Poverty Index}

The Foster, Greer and Thorbecke (FGT) measures of poverty are widely used because they are consistent and additively decomposable (Foster et al., 1984).This was used to achieve the objective of this study. Poverty head count index, poverty gap index and squared poverty gap index were computed to measure the incidence, depth and severity of poverty among the beef cattle value chain actors. A relative poverty line was constructed based on the Mean Per Adult-equivalent Household Expenditure (MPAHE) of the beef cattle value chain actors. To account for intrahousehold composition in estimating household expenditure, the modified OEDC equivalence scale was used to calculate the adult-equivalent household size (OEDC, 2008). The scale assigns a value of 1 to the first adult household member, 0.5 to each additional adult member and 0.3 to each child in calculating adult-equivalent household size. The general Foster, Greer and Thorbecke (FGT) poverty index $\left(\mathrm{P}_{\alpha \mathrm{i}}\right)$ can be expressed as:

$$
\begin{aligned}
& P_{\alpha i}=\frac{1}{n} \sum_{i=1}^{q}\left(\frac{z-y_{i}}{z}\right)^{a} \\
& \text { When: } \\
& a=0, \quad P_{0}=\frac{1}{n} \sum_{i=1}^{q}\left(\frac{z-y i}{z}\right)^{0}=\frac{q}{n} \\
& a=1, \quad P_{1}=\frac{1}{n} \sum_{i=1}^{q}\left(\frac{z-y i}{z}\right)^{1} \\
& \text { i.e poverty gap or depth } \\
& a=2, P_{2}=\frac{1}{n} \sum_{i=1}^{q}\left(\frac{z-y t}{z}\right)^{2} \text {. } \\
& \text { i.e poverty severity }
\end{aligned}
$$




\section{Rekwot, Oyinbo and Achi}

Where,

$\mathrm{n}=$ number of households in a group

$\mathrm{q}=$ the number of poor households

$\mathrm{z}=$ poverty line $(2 / 3$ Mean Per Adult-

equivalent Household Expenditure (MPAHE) of the beef value chain actors)

$\mathrm{y}=$ the per adult-equivalent expenditure (PAE) of the $i^{\text {th }}$ household, $\alpha=$ degree of poverty aversion $(0,1$ and 2$)$

\section{Pearson correlation analysis}

The analysis produces a correlation coefficient $r$ known as Pearson correlation coefficient (product-moment correlation coefficient). This coefficient is a statistical measure of the strength of a linear relationship between two variables (income generated from beef cattle value chain participation and poverty status of value chain actors). This was also used to test the hypothesis which states that "there is no significant relationship between the income realized from beef cattle value chain participation and the poverty status of the value chain actors". The range of correlation coefficient is between -1 and +1 and a correlation coefficient greater than 5 is often considered as an indication of a strong or high correlation in empirical studies (Sharma et al., 2011; Darkwahet al., 2019). The correlation coefficient (r) is estimated as follows:

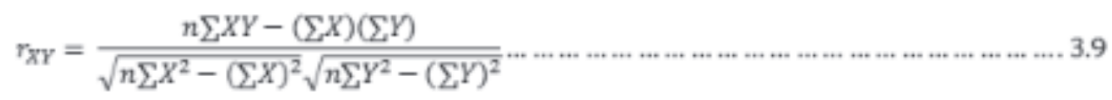

Where:

$\mathrm{r}=$ correlation coefficient

$\mathrm{X}=$ beef cattle value chain participation expressed as the income generated from beef cattle value chain measured using the net income analysis

$\mathrm{Y}=$ poverty status of the various value chain actors expressed by the incidence of poverty measured using the FGT weighted poverty indices.

\section{Results and discussion \\ Socioeconomic characteristics of beef cattle value chain actors}

The age distribution of the value chain actors as shown in Table 1 revealed that majority of the raw beef marketers $(51.7 \%)$ and processed beef marketers $(61.7 \%)$ were within the age bracket of 20-39 years and had mean ages of 45 and 38 years respectively and standard deviation of 10 to 14 years respectively. Also, the results showed that a larger proportion of the cattle farmers (53.3) and traders (50\%) were within the age bracket of 40-59 years with mean ages of 45 and 44 years respectively and standard deviation of 10 to 14 years, respectively.These results imply that majority of the value chain actors are within the economically active and productive age group, and as such are able to bear the rigors of beef cattle value addition activities. In this regard, age determines how active and productive value chain actors can be in the performance of their activities (Ngore et al., 2011). Results of the analysis presented in Table 1 showed that majority of the cattle farmers $(71.7 \%)$ had no formal education. About half $(50 \%)$ of the cattle traders and raw beef marketers had one form of formal education while a larger percentage (55\%) of the processed beef marketers had one form of formal education or the other.The lack of formal education by majority of the cattle farmers implies that the benefits of education in enhancing the learning processes in adoption of improved technologies and management practices for increased livestock productivity and market-oriented production is likely limited (Foster and Rosenzweig, 2010). The results in Table 1 showed that a larger percentage of the cattle farmers $(40.8 \%)$, traders $(36.7 \%)$, 


\section{Poverty reduction among beef cattle value chain actors}

and processed beef marketers $(35.0 \%)$ had household size of 6-10 persons and mean household size of 9,13, 12 and 9 persons per household, respectively. Also, the results show that a larger proportion of the raw beef marketers $(31.7 \%)$ had household size of 11-15 persons with mean household sizes of 10 and 12 persons per household respectively. In general, the value chain actors had mean household size of 6 to 13 persons per household and this implies that value chain actors with larger household size are likely to have more family labour supply for their beef cattle value addition activities and other household activities. However, such large household size could imply more burden on feeding and other basic necessities for the large households.

Results on the years of experience of value chain actors showed that a larger proportion of the famers $(36.7 \%)$, traders $(51.7 \%)$, raw beef marketers $(43.3 \%)$ and processed beef marketers $(38.3 \%)$ had $11-20$ years of experience in their respective beef cattle value chain activities. Overall, the beef cattle value chain actors had average years of experience of 19 to 23 years, which implies that they have acquired a lot of experience in proper management of their beef cattle value chain activities over the years, which is an important human capital that can influence their production efficiency. The results on cooperative membershiprevealed that majority of the farmers $(55.0 \%)$ do not belong to any form of cooperative societies, thereby depriving them from the opportunity of obtaining not only credit and productive inputs, but also information on how to improve their productivity. The results further indicated that a larger proportion of the cattle traders $(83.3 \%)$ raw beef marketers $(73.3 \%)$, and processed beef marketers $(75.0 \%)$ were members of cooperative societies. These findings corroborated that of Dauda et al. (2018) that majority (73\%) of the cattle farmers sampled in Yobe state do not belong to a cooperative. Majority of the raw beef marketers $(60.0 \%)$ and processed beef marketers $(55.0 \%)$ had access to credit for their beef value addition activities. Also, the results show that a larger proportion of the cattle farmers $(65.0 \%)$ and traders $(63.3 \%)$ had no access to credit. The lack of access to credit by some of the beef cattle value chain actors especially the cattle farmers can constitute a constraint for adoption of improved technologies and management practices to enhance their beef cattle value addition activities. Result from the field survey revealed that majority of beef cattle farmers $(78.3 \%)$ had no contactwith extension agent. This implies that there is limited access to information on improved technologies and management practices such as improved livestock nutrition, reproduction and other services. This is important because of the crucial role of access to livestock extension services in creating the platform for acquisition of the relevant information that promotes technology adoption for livestock production and market access (Adisa, 2015).

\section{Poverty profile of beef cattle value chain actors}

The result of the poverty profile of beef cattle value chain actors in the study area is presented in Table 2. Based on the food and non-food consumption expenditure of the value chain actors, the relative poverty line was estimated to beN75, 600. Using the relative poverty line of N75, 600 in the study area, the poverty headcount index which is the share of the beef value chain actors whose per-adult equivalent consumption expenditure per annum is below the poverty line is $0.55,0.32,0.40$ and 0.38 for beef cattle farmers, traders, raw beef marketers and processed beef marketers respectively. This implies that $55,32,40$ and $38 \%$ of the beef cattle farmers, traders, raw beef marketers and processed beef marketers respectively 
Rekwot, Oyinbo and Achi

Table 1: Socioeconomic characteristics of beef cattle value chain actors

\begin{tabular}{|c|c|c|c|c|}
\hline $\begin{array}{l}\text { Socio-economics } \\
\text { characteristics }\end{array}$ & Farmers & Traders & $\begin{array}{l}\text { Raw beef } \\
\text { marketers }\end{array}$ & $\begin{array}{l}\text { Processed beef } \\
\text { marketers }\end{array}$ \\
\hline \multicolumn{5}{|l|}{ Age (Years) } \\
\hline $20-39$ & $41(34.2)$ & $26(43.3)$ & $32(51.7)$ & $37(61.7)$ \\
\hline $40-59$ & $64(53.3)$ & $30(50.0)$ & $28(45.0)$ & $21(35.0)$ \\
\hline $60-79$ & $15(12.5)$ & $4(6.7)$ & $2(3.3)$ & $2(3.3)$ \\
\hline Mean & 45.3 & 43.9 & 42.4 & 38.2 \\
\hline S. D & 13.8 & 10.6 & 10.4 & 10.7 \\
\hline \multicolumn{5}{|l|}{ Education } \\
\hline No formal & $86(71.7)$ & $32(53.3)$ & $31(51.7)$ & $27(45.0)$ \\
\hline Primary & $18(15.0)$ & $12(20.0)$ & $12(20.0)$ & $14(23.3)$ \\
\hline Secondary & $13(10.8)$ & $16(26.7)$ & $11(18.3)$ & $16(26.7)$ \\
\hline Tertiary & $3(2.5)$ & $0(0.0)$ & $6(10.0)$ & $3(5.0)$ \\
\hline \multicolumn{5}{|l|}{ Household size } \\
\hline $1-5$ & $39(32.5)$ & $5(8.3)$ & $12(20.0)$ & $18(30.0)$ \\
\hline $6-10$ & $49(40.8)$ & $22(36.7)$ & $15(25.0)$ & $21(35.0)$ \\
\hline $11-15$ & $18(15.0)$ & $14(23.3)$ & $19(31.7)$ & $14(23.3)$ \\
\hline $16-20$ & $9(7.5)$ & $11(18.3)$ & $8(13.3)$ & $3(5.0)$ \\
\hline $21-25$ & $5(4.2)$ & $8(13.3)$ & $6(10.0)$ & $4(6.7)$ \\
\hline Mean & 8.6 & 12.9 & 11.6 & 9.1 \\
\hline \multicolumn{5}{|l|}{ Year of experience } \\
\hline $1-10$ & $27(22.5)$ & $5(8.3)$ & $3(5.0)$ & $13(21.7)$ \\
\hline $11-20$ & $44(36.7)$ & $31(51.7)$ & $26(43.3)$ & $23(38.3)$ \\
\hline $21-30$ & $30(25.0)$ & $15(25.0)$ & $19(31.7)$ & $20(33.3)$ \\
\hline $31-40$ & $19(15.8)$ & $9(15.0)$ & $12(20.0)$ & $4(6.7)$ \\
\hline Mean & 22.9 & 21.5 & 23.2 & 19.3 \\
\hline \multicolumn{5}{|l|}{$\begin{array}{l}\text { Co-operative } \\
\text { membership }\end{array}$} \\
\hline Yes & $54(45.0)$ & $50(83.3)$ & $44(73.3)$ & $45(75.0)$ \\
\hline No & $66(55.0)$ & $10(16.7)$ & $16(26.7)$ & $15(25.0)$ \\
\hline \multicolumn{5}{|l|}{ Access to Credit } \\
\hline Yes & $42(35.0)$ & $22(36.7)$ & $36(60.0)$ & $33(55.0)$ \\
\hline No & $78(65.0)$ & $38(63.3)$ & $24(40.0)$ & $27(45.0)$ \\
\hline \multicolumn{5}{|l|}{$\begin{array}{l}\text { Access to extension } \\
\text { services }\end{array}$} \\
\hline Yes & $26(21.7)$ & & & \\
\hline No & $94(78.3)$ & & & \\
\hline Total & 120 & 60 & 60 & 60 \\
\hline
\end{tabular}

constituted the share of the population that cannot afford to buy a basic basket of goods (food and non-food) equivalent to the poverty line. In comparison with the other value chain actors, the results show that the prevalence of poverty is higher among the beef cattle farmers. Also, the incidence of poverty among the beef cattle farmers compares favorably with the $59 \%$ incidence of poverty reported for North-west region of Nigeria (UNDP, 2018). The depth of poverty (poverty gap index) of poor beef cattle traders $(0.08)$ was lower than that of the poor beef cattle farmers $(0.17)$, raw beef marketers (0.10) and processed beef marketers (0.14). This indicates that the poor beef cattle farmers, raw beef marketers and processed beef marketers are farther away from the poverty line than the poor beef cattle traders and the implication is that it is easier for beef cattle traders to move above the poverty line or move out of the poverty trap than the other value chain actors. The degree of inequality (squared poverty gap index or poverty severity) among the poor beef cattle traders given by 


\section{Poverty reduction among beef cattle value chain actors}

the estimated severity of poverty (0.03) was equally lower than that of the poor beef cattle farmers (0.08), raw beef marketers (0.04) and processed beef marketers (0.07). This shows that poverty tends to be less severe among cattle traders than the other value chain actors. From the poverty profile of beef cattle value chain actors based on the three poverty indices, it can be deduced that the beef cattle farmers were worst off in terms of poverty in comparison with the other value chain actors. This is likely connected in part to the gross inefficiency of beef cattle production (Nwigwe et al., 2016) and low marketoriented cattle production amongst others (Kubkomawa et al., 2015).

Table 2: Distribution of poverty indices of beef cattle value chain actors

\begin{tabular}{llll}
\hline Actors & Poverty headcount & Poverty gap & Poverty severity \\
\hline Farmers & 0.55 & 0.17 & 0.08 \\
Traders & 0.32 & 0.08 & 0.03 \\
Raw beef marketers & 0.40 & 0.10 & 0.04 \\
Processed beef marketers & 0.38 & 0.14 & 0.07 \\
\hline
\end{tabular}

Relationship between income generated from beef cattle value chain and poverty status of value chain actors

The results of the correlation analysis presented in Table 3 showed that the income generated from beef cattle value chain participation by cattle farmers is negatively related to their poverty status as indicated by a correlation coefficient of -0.53 and the relationship is statistically significant at $5 \%$ probability level. This indicates that an increase in the income generated from cattle production node of the beef cattle value chain is strongly associated to a decrease in the likelihood of poverty among the cattle farmers and vice versa. This finding implies that active participation of cattle farmers in beef cattle value chain can be a viable means of alleviating poverty. This is consistent with the findings of Irou et al. (2018) that the returns realized from participating in fish production aspect of fish value chain significantly decreases poverty at $1 \%$ probability level. This is also in line with Kristjanson et al. (2010) and Devaux et al. (2016) who opined that an inclusive value chain with sustainable access by small-scale producers to markets and increased profits earned can generate social benefits such as poverty reduction.

The results of the correlation analysis presented in Table 3 showed that there was a statistically significant negative relationship between the income generated from cattle trading and the poverty status of the cattle traders as indicated by a correlation coefficient of -0.66 . This suggests that an increase in income realized from participation in beef cattle value chain by cattle traders is strongly associated to a reduction in the likelihood of poverty among the cattle traders. In line with this, Mafimisebi et al. (2014) noted that the outcome of enhanced marketing of cattle and its products especially beef can potentially lead to better income and living standard in a study on cattle marketing in south-west Nigeria.The results of the correlation analysis presented in Table 3revealed that the income generated from beef cattle value chain participation by raw beef marketers is negatively related to their poverty status as indicated by a correlation coefficient of -0.64 and the relationship is statistically significant at $1 \%$ probability level. This indicates that an increase in the income generated from value addition through raw beef marketing is strongly 


\section{Rekwot, Oyinbo and Achi}

associated to a decrease in the likelihood of poverty among the raw beef marketers. This corroborates Ari et al. (2016) who noted that livestock production systems and marketing represent a potential pathway out of poverty for many smallholders' livestock value chain actors. The results of the correlation analysis presented in Table 3 showed that the income generated from beef cattle value chain participation by processed beef marketers was negatively related to their poverty status as indicated by a correlation coefficient of -0.71 and the relationship is statistically significant at $1 \%$ probability level. This implies that opportunities to increase income realized from participation in beef cattle value chain by the processed beef marketers is strongly associated to a reduction in the likelihood of poverty among the processed beef marketers. This corroborates Etuk et al. (2015) who found that participation in fish value chain as dry fish vendor (processed fish)was negative and significant in reducing the probability of being poor among the dry fish vendors in Cross River and AkwaIbom states.

Table 3: Relationship between income generated from beef cattle value chain and poverty status of value chain actors

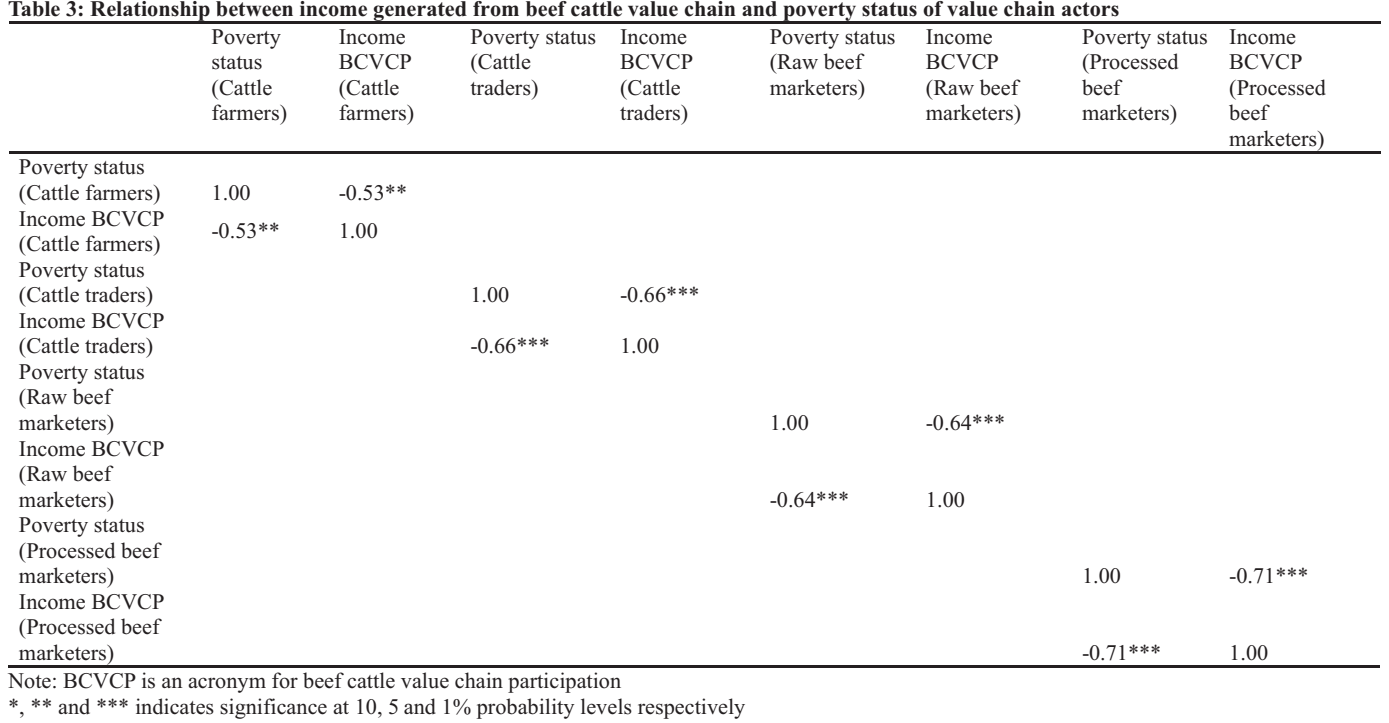

\section{Conclusion and recommendation}

The findings of the study showed that the relationship between income generated is strongly associated to the livelihood of poverty reduction among the value chain actors. This indicates that active participation of beef cattle farmers, beef cattle traders, raw and processed beef marketers in beef cattle value chain activities can be a viable means of alleviating poverty and improve the welfare of value chain actors in the study area. It is therefore recommendedthat, beef value chain actors should take advantage of the huge potential investment opportunities in beef cattle value chain activities.

\section{References}

Abubakar, I. and Ibrahim, U. 2019. A Macroeconomic Analysis of Agricultural Sector in Nigeria. Advanced Journal of Social Science, 5(1): 18-25.

Adesoye, B.A., Adelowokan, O. A., Maku, E. O. and Salau, S. O. 2018. Enhancing Agricultural Value Chain for Economic Diversification in Nigeria. African Journal of Economic Review, 6(1): 103-118. 
Ademola, O. T., Olawale, O. E. and Abiodun, B. S. 2019. Building and Integration of Agricultural Value Chains in Nigeria. Canadian Foreign Policy Journal, 25(3): 254-268.

Adisa, R.S. 2015. Livestock extension practice and competency among agricultural extension agents in North-Central Nigeria.South African Journal of Agricultural Extension, 43(1): 12-21.

Ari, M. M., Ogah, D.M. and Luka, E.G. 2016. Livestock value chain development in Nigeria: institutional framework and opportunities for chain actors. Journal of Biology, Agriculture and Healthcare, 6(9): 34-40.

Bobola, O.M., Mafimisebi, T.E. and Ikuemonisan, E.S. 2015. Price fluctuations, linkages and causality in the Nigerian beef market. Journal of Fisheries and Livestock Production, 3(2): 1-9.

Dauda, I. B., Makinde, O. J and Oyediran, B. O. 2018. Analysis of Cost and Returns of Cattle Marketing in Bade Local Government Area, Yobe State, Nigeria. International Journal of Agricultural Research, Sustainability, and Food Sufficiency, 5(1): 229-236.

Darkwah, K.A., Kwawu, J.D., AgyireTettey, F. and Sarpong, D.B. 2019 . Assessment of the determinants that influence the adoption of sustainable soil and water conservation practices in Techiman Municipality of Ghana. International Soil and Water Conservation Research, In press.

Devaux, A., Torero, M., Donovan, J. and Horton, D. 2016. Innovation for Inclusive value-chain development: Successes and challenges. International Food
Policy Research Institute. Was hington, D C. I S B N 9780896292130.

East African Business Council \{EABC $\} 2020$. Impact of Covid-19 on the Agriculture Sector in the EAC. The Voice of the Private Sector in East Africa.

Etuk, E., Angba, C. and Angba, A. 2015. Determinants of Poverty Status of Fish Vendor Households in Lower Cross River basin, Nigeria. Journal of Economics and Sustainable Development, 6(14): 50-55.

Federal Ministry of Agriculture and Rural Development (FMARD), 2016. The Agriculture Promotion Policy (2016 - 2020): Building on the Successes of the ATA, Closing Key Gaps. Policy and Strategy Document.

Federal Ministry of Agriculture and Rural Development (FMARD) and Federal Government of Nigeria, 2019. National Livestock Transformation Plan (2019-2028): Implementation Plan Guidelines for FGN and States. Policy Document.

Foster, J., Greer, J. and Thorbecke, E. 1984. A class of decomposable poverty measures.Econometrica, 52: 761-66.

Foster, A.D. and Rosenzweig, M.R. 2010. Microeconomics of technology adoption. Annual Review of Economics, 2:395-424.

Girei, A. A., Dire, B. and Bello, B. H. 2013. Assessment of Cost and Returns of Cattle Marketing in Central Zone of Adamawa state, Nigeria. British Journal of Marketing Studies, 1(4):1-10.

Iruo, F.A., Onyeneke, R.U., Eze, C.C., Uwadoka, C. and Igberi, C.O. 2018. Economics of smallholder fish farming to poverty alleviation in the Niger Delta Region of 
Nigeria. Turkish Journal of Fishery and Aquatic Science, 19(4): 2-14.

Kristjanson, P., Mango, N., Anirudh, Krishna, A., Radeny, M. and Johnson, N. 2010. Understanding poverty dynamics in Kenya. Journal of international development, pp.1-22.

Kubkomawa, H.I., Krumah, L. J., Etuk, E.B. and Okoli, I.C. 2015. Current Pastoral Cattle Production Situation in West Africa: A review. Dynamic Journal of Animal Science and Technology, 1(1): 117.

Mafimisebi, T.E., Bobola, O.M. and Mafimisebi, O.E. 2014. Fundamentals of cattle marketing in Southwest, Nigeria: Analyzing market intermediaries, price formation and yield performance. Applied Tropical Agriculture, 19(1):30-38.

Muftah, S. A. 2017. Economic Diversification in Recession: A Case of Nigerian Agriculture as a Sign of Post for National Development and Sustainable Growth. International Journal of Advanced Studies in Economics and Public Sector Management, 5(1):52-73.

National Bureau of Statistics (NBS), 2018. Labor Force StatisticsVolume 1: Unemployment and Underemployment Report.

Nigeria Bureau of Statistics (NBS) and Federal Ministry of Agriculture and Rural Development (FMARD) 2012. Collaborative Survey on National Agricultural Sample Survey (NASS), Draft Report. Nigeria Bureau of Statistics, Abuja, pp 35-98.

National Population Commission (NPC), 2006. Official Census Figures. NPC, Abuja, Nigeria.

Ngore, P.M., Mshenga, P.M., Owuor, G. a n d M u t a i, B . K . 2011. Socioeconomic Factors Influencing Meat Value Addition by Rural Agribusinesses in Kenya. Current Research Journal of Social Sciences, 3(6): 453-464.

Nwigwe, C., Okoruwa, V., Adenegan, K. and Olajide, A. 2016. Technical Efficiency of Beef Cattle Production Technologies in Nigeria: A Stochastic Frontier Analysis. African Journal of Agricultural Research, 11(51): 5152-5161.

Organization for Economic Cooperation and Development (OEDC), 2008. Growing Unequal? Income Distribution and Poverty in OEDC Countries, Paris.

PricewaterhouseCoopers Limited (PWC), 2020. Responding to the Impact of Covid-19 on Food Security and Agriculture in Nigeria. PricewaterhouseCoopers International Limited, June, 2020.

Sharma, A., Bailey, A. and Fraser, I. 2011. Technology adoption and pest control strategies among UK cereal farmers: Evidence from parametric and nonparametric count data models. Journal of Agricultural Economics, 62: 73-79.

United Nations Development Programme (UNDP), 2018. National Human Development Report 2018: Achieving Human Development in North East Nigeria.

World Bank 2017. Livestock Productivity and Resilience Support Project (p 160865 ) Information Document/Integrated Safeguards Data Sheet (PID/ISDS). World Bank, Washington, DC.

Received: $4^{\text {th }}$ September, 2021 Accepted: $10^{\text {th }}$ December, 2021 